\title{
Magnesium pemoline and EEG sleep patterns in man
}

\author{
FREDERICK BAEKELAND AND RICHARD LASKY \\ STATE UNIVERSITY OF NEW YORK, DOWNSTATE MEDICAL CENTER
}

The effects of a single 25-mg dose of the alerting agent, magnesium pemoline, on the EEG-recorded sleep patterns of 10 normal Ss was studied by giving them either the drug or a placebo on two occasions a week apart just before bed. Over a 6-h sleep period magnesium pemoline had no effect on recorded sleep except to increase the frequency of rapid eye movements (REMs) within REM periods.

Magnesium pemoline has been shown to be a central stimulant (Lienert \& Janke, 1957) and to enhance performance in objective psychological tests (Lienert \& Janke, 1957; Dureman, 1962; Talland, 1966). The drug appears to have mild alerting effects at the $25-\mathrm{mg}$ dose level as does $5 \mathrm{mg}$ of methyl phenidate. Since methyl phenidate $5 \mathrm{mg}$ has been shown to affect sleep patterns (Baekeland, 1966), it seemed of interest to determine whether magnesium pemoline $25 \mathrm{mg}$ has similar effects on sleep

Method

Eight college students and two night workers in their early $30 \mathrm{~s}$ served as Ss. They last ate at least $4 \mathrm{~h}$ before bed, when they received, p.o. and double blind, either magnesium pemoline $25 \mathrm{mg}$ or a placebo on two occasions a week apart according to a balanced design. Continuous EEG and electrooculogram recordings were taken, and Ss slept for at least $6 \mathrm{~h}$. Records were scored blind for the following parameters: time from lights out to sleep onset (sleep latency), time from sleep onset to the onset of the first rapid eyemovement period (REMP 1 latency), frequency of REMs within REMPs (REM density) and the conventionally defined stages of sleep (stages 0 or wakefulness,

Table 1. Sleep Stages: Minutes Accumulated Over 2 and $6 \mathrm{~h}$ of Sleep.

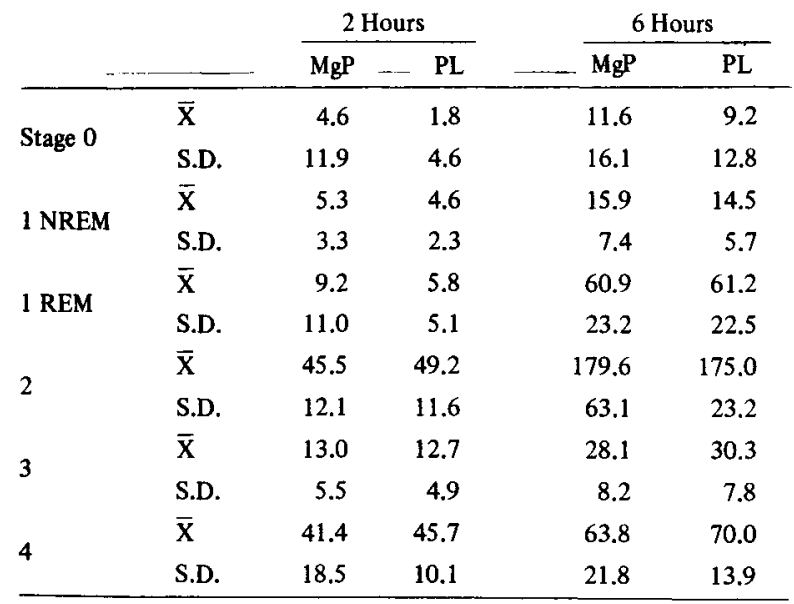

Table 2. Effects of Magnesium Pemoline (MgP) and Placebo (PL) on Sleep Latencies, First REMP Latencies and REM Density.

\begin{tabular}{lccc} 
& MgP & PL & p \\
\hline Sleep latency $(\min )$. & $18.6 \pm 17.1$ & $8.9 \pm 7.3$ & n.s. \\
REMP $_{1}$ latency & $110.6 \pm 42.6$ & $107.8 \pm 38.1$ & n.s. \\
REM density & $0.151 \pm 0.061$ & $0.101 \pm 0.035$ & $<.05^{*}$ \\
\hline
\end{tabular}

*Two-tailed $t$ test.

1 non-REM (NREM), 2, 3, and 4). Recording procedures and scoring criteria have been described elsewhere (Baekeland, 1966).

\section{Results}

Magnesium pemoline had surprisingly little effect on sleep. It failed to change the amount of time spent in any stage of sleep, either over the first $2 \mathrm{~h}$ of sleep or over the total 6-h sleep period (Table 1) and it did not affect sleep latency or REMP 1 latency. However, it did increase mean REM densities (0.151 vs 0.101 , p < .05)(Table 2).

\section{Discussion}

At the 25-mg dose level magnesium pemoline had remarkably little effect on sleep. Unlike $5 \mathrm{mg}$ of methyl phenidate (Baekeland, 1966), which is also a central stimulant, it did not increase $R E M P_{1}$ latencies, reduce REMP time or lighten sleep in the sense of increasing Stage 2 at the expense of Stages 3 and 4. The only effect it seemed to have was to increase REM densities, in contrast with the ineffectiveness in this regard of methyl phenidate (Baekeland, 1966).

It has been argued (Rabkin, 1964) that increases in REM density might be interpreted in terms of nonspecific drive activation and discharge. Hence, it is tempting to suppose that magnesium pemoline may facilitate the often proposed drive discharge function of dreaming.

The drug's failure to affect the sleep cycle is reminiscent of the reported ineffectiveness of caffeine in this regard (Gresham, Webb, \& Williams, 1963). In view of their inability to affect REM sleep, it is not surprising that both magnesium pemoline and caffeine have been reported ineffective (Akimoto, Honda, \& Takahashi, 1960) in the treatment of the sleep attacks and cataplexy of narcolepsy, a disorder characterized by the rapid onset and precocious triggering of REM sleep (Dement, Rechtschaffen, \& Gulevich, 1966), while methyl phenidate, which inhibits REM sleep, is effective in the treatment of narcolepsy (Yoss \& Daly, 1960).

The failure of magnesium pemoline at the $25-\mathrm{mg}$ dose level to delay sleep onset or to increase wakefulness agrees with clinical reports (Fujita, Tanaka, Funasaka, \& Kamamura, 1961; Matsumoto, Yamagami, 
\& Ishikawa, 1961; Shinozaki, Sugita, \& Mori, 1961) that insomnia is an uncommon side effect of the drug in patients.

References

AKIMOTO, H., HONDA, Y., \& TAKAHASHI, Y. Pharmacotherapy in narcolepsy. Dis. nerv. Syst., 1960, 21, 704706.

BAEKELAND, $F$. The effect of methyl phenidate on the sleep cycle in man. Psychopharmacologia (Berl.), 1966, 10, 179-183.

DEMENT, W., RECHTSCHAFFEN, A., \& GULEVICH, G. The nature of the narcoleptic sleep attack. Neurology, 1966, 9, 673-689.

DUREMAN, E. I. Differential patterning of behavioral effects from three types of stimulant drugs. Clin. pharmacol. Therapeut., 1962, 3, 29-33.

LIENERT, G. A., \& JANKE, W. Pharmakologische Untersuchung über 5-phenyl-2-imino-4oxo-oxazolidin. Arzneimittel-Forsch., 1957, 7, 436-439.

MATSUMOTO, Y., YAMAGAMI, R., \& ISHIKAWA, T. Clinical ex- periences with phenyl isohydantoin in psychotic and psychoneurotic disorders. Seishin Igaku, 1961, 3, 155-160.

RABKIN, R. Rapid eye movements and drive theory. Amer. J. Psychiat., $1964,121,600-601$.

SHINOZAKI, T., SUGITA, T., \& MORI, H. Clinical experiences of phenyl-isohydantoin (5-phenyl-2-imino-oxo-oxazolidin). Seishin Igaku, 1961, 3, 533-540.

TALLAND, G. A. Improvement of sustained attention with Cylert. Psychon. Sci, 1966, 6, 493-494.

YOSS, R. E., \& DALY, D. Narcolepsy. Med. Clin. N. Amer., 1960, 44, 953-968.

Notes

1. This research was supported by a grant from Abbott Laboratories, Scientific Divisions, Chicago, Illinois.

2. The author holds a group 1 Career Development Award (MH-23,901) from the United States Public Health Service, National Institute of Mental Health. 